\title{
THE PROFITABILITY, FIRM'S SIZE, DIVIDEND PAYOUT RATIO AND FIRM'S VALUE: CAPITAL STRUCTURE INTERVENTION
}

\author{
Christina Heti Tri Rahmawati * \\ Sanata Dharma University, Indonesia
}

\begin{abstract}
This research aims to investigate the influence of profitability, firm's size, and dividend payout ratio towards firm's value with the capital structure as the intervening variable. The samples employed were the manufacturing companies registered in Indonesia Stock Exchange from 2016-2018. The statistic method used to investigate the hypothesis was a path analysis. The result of the hypothesis investigation proved that the profitability brought significant negative influence towards capital structure, the firm's size and dividend payout ratio brought insignificant influence towards capital structure; the profitability, firm's size, dividend payout ratio, and capital structure brought significant positive influence towards the firm's value. On the other hand, the intervening testing results proved that the capital structure intervened in the influence of the profitability towards the firm's value, and the capital structure did not intervened in the influence of the firm's size and dividend payout ratio towards the firm's value. Being able to pick stocks with profitability value and high dividend payout ratio and choosing a large-scale company are the research implications for investors to scale up the firm's value. Furthermore, companies can increase profitability, pay higher dividend, and choose a large-scale company by balancing the capital structure, so that firm's value increases.
\end{abstract}

JEL: G32, G35

Keywords : profitability, firm's size, dividend payout ratio, firm's value, capital structure.

\begin{abstract}
ABSTRAK
Penelitian ini bertujuan untuk menguji pengaruh profitabilitas, ukuran perusahaan dan kebijakan dividen terhadap nilai perusahaan dengan struktur modal sebagai variabel mediasi. Sampel yang digunakan adalah perusahaan manufaktur yang terdaftar di Bursa Efek Indonesia dari tahun 2016 sampai dengan 2018. Metode statistik untuk menguji hipotesis menggunakan analisis jalur. Hasil pengujian hipotesis membuktikan bahwa profitabilitas berpengaruh negatif signifikan terhadap struktur modal, ukuran perusahaan dan kebijakan dividen tidak berpengaruh signifikan terhadap struktur modal; profitabilitas, ukuran perusahaan, kebijakan dividen dan struktur modal berpengaruh positif signifikan terhadap nilai perusahaan. Sedangkan hasil uji mediasinya membuktikan bahwa struktur modal memediasi pengaruh profitabilitas terhadap nilai perusahaan; serta struktur modal tidak memediasi pengaruh ukuran perusahaan dan kebijakan dividen terhadap nilai perusahaan. Implikasi penelitian ini bagi investor dapat melakukan pemilihan saham yang mempunyai nilai profitabilitas dan pembayaran dividen tinggi serta memilih perusahaan yang ukurannya besar, sehingga nilai perusahaan meningkat. Sedangkan bagi perusahaan dapat meningkatkan profitabilitas, melakukan pembayaran dividen tinggi dan memilih perusahaan yang ukurannya besar dengan menyeimbangkan struktur modal, sehingga nilai perusahaan meningkat.
\end{abstract}

Kata Kunci : profitabilitas, ukuran perusahaan, kebijakan dividen, nilai perusahaan, struktur modal.

\section{INTRODUCTION}

In this industrialization era, every company must gain competitive profits by putting extra attention on its operational and financial plans. Therefore, large-scale companies will be targeted investors who invest their capital so as to get the maximum profit. This is in line with the goal of companies that is to maximize the affluence and well-being of stakeholders giving a return in the

\footnotetext{
*Email : christinaheti.nugroho@yahoo.co.id

Received : 04-03-2020, Accepted: 23-12-2020, Published : 28-12-2020

P-ISSN : 2087-9954, E-ISSN : 2550-0066. DOI : http://dx.doi.org/10.26418/jebik.v9vi3.39765
} 
form of a dividend payout ratio or capital gain. The goal can be achieved by maximizing the market value of the company's stocks, where the higher the firm's value will reflect in the more affluent stakeholders. The manufacturing industry could grow by $5.01 \%$ in 2006 . However, the economic growth and manufacturing industry respectively experienced a decline of 3\% and 3.89\% in 2017. The low average of industry growth compared to the economic growth has worsened the role of the manufacturing industry sector on Gross Domestic Product.

The firm's value is an investor's perception of the company that is frequently linked to the stock price. The high value of a firm shows its great working performance quality so the investors will apprehend the company positively. Furthermore, the firm's value will be reflected in the price of the company's stocks. However, a company will not only be rated from its high stock prices but also its financial decision making, for example through the dividend payout ratio. The dividend payout ratio is a verdict of the net profit value that will either be shared with stakeholders in a form of dividends or be held to fund future investments. The huger the net profit value is, the more the stakeholders obtain the dividend (Laksana \& Widyawati, 2016).

In this research, the firm's value is measured by the Price to Book Value (PBV), a dividend payout ratio towards the book's value from the firm where the invested capital is shown through the firm's ability in creating the relative values (Prastuti \& Sudhiarta, 2016). The PBV ratio is used as it can figure out whether the stock's cost is overvalued or undervalued from its book. Therefore, it can evaluate the highs and lows of the firm's value which is reflected through the stock's cost (Ayu \& Suarjaya, 2017). Several factors affecting the firm's values, for instance, dividend payout ratio, funding decision, firm's growth, investment decision, profitability, and firm's size. However, this research will only discuss three factors influencing the firm's value, such as profitability, the firm's size, and dividend payment ratio. This happens due to the inconsistent results on the previous research discussing the profitability, firm's size, and the dividend payment ratio towards both the direct and indirect good firm's value.

According to Sastrawan (2016), profitability is considered essential as it plays a role as an indicator in measuring the company's financial performance which can be a reference to assess a company. In this research, the profitability itself will be measured by Return on Assets (ROA) which can rate the ability of the company in earning profits from the total assets used (Musabbihan \& Purnawati, 2018). Meanwhile, the firm's size is an indicator that shows the financial strength of a firm and is believed to affect the firm's value (Hermuningsih, 2012). The more the company shows that it constantly develops, the easier it acquires both internal and external funding sources. It, therefore, can lift the firm's value up. In this research, the firm's size is seen through the total assets owned by a company that can be utilized to organize the company's operational activities and be measured by using the size proxy (Novari \& Lestari, 2016).

The dividend payout ratio is a stipulation on how huge the profits will be shared with the stakeholders (Nofrita, 2013). The price of stocks is possibly influenced by the big amount of dividend, where the stocks' price will be relatively higher when the dividend is highly paid so that the firm's value will also enhance and vice versa (Jusriani, 2012). In this research, the dividend payout ratio is measured based on how big the amount of dividend shared with the stakeholders and can be seen with the Dividend Payout Ratio or DPR (Musabbihan \& Purnawati, 2018).

The previous research found some inconsistent results with the theory related to the influence of profitability, the firm's size, and dividend payout ratio toward the firm's value. 
Therefore, the researcher reckons that another variable influences those three variables towards the firm's value, which is a capital structure. In this research, the capital structure is used as a variable that intervenes the other three variables towards the company's value. It happens because when the company reaches its highest profit, the firm's size is automatically getting bigger and able to share bigger dividends to its stakeholders. It thus can lift the firm's value up. In this context, the progressive values of a firm are also triggered by the existence of the optimum capital structure in deciding the funding sources for the firm's productivity. Those three factors, profitability, firm's size, and the dividend payout ratio affect the allocation of the funding sources for the company's productivity that finally gives a positive impact on the firm's value.

In the previous research, the researcher also employed the capital structure as a variable that intervened the firm's value and found out the inconsistent research results. Hermuningsih, (2012); Anjarwati, Chabachib \& Demi (2017); and Musabbihan \& Purnawati (2018) declare that the capital structure can intervene the influence of profitability towards the company's value. On the contrary, Musabbihan \& Purnawati (2018), Amelia \& Khaerunnisa (2016), and Rubiyani \& Yuniati (2016) in their research claim that the capital structure cannot intervene the influence of profitability towards the company's value. The capital structure is a funding policy between debt and equity to optimize the firm's value. This research uses Debt to Equity Ratio (DER) to judge the capital structure which displays the capital compositions used as the funding (Musabbihan \& Purnawati, 2018). Due to the low value of manufacturing companies and the sources inconsistency of previous research results, the researcher is interested in investigating the influence of profitability, the firm's size, and dividend payout ratio towards the firm's value with the capital structure as the mediating variable.

\section{LITERATUR REVIEW}

\subsection{Signaling Theory}

Signaling theory is a decision taken by a company to guide investors about how management views the company's prospects . The signal is in the form of information about what has been done by the management to realize the owner's demands. The company's information is important for the owners of companies as they consider the information to be a signal that can help the owners to decide whether they need to reinvest the capital to the company (Jensen \& Meckling, 2011). Signaling theory occurs because of the information asymmetry caused by management knowing more about the company's prospects. To avoid information asymmetry, the company must deliver information as a signal to the investors (Muvidha \& Suryono, 2017). One of the types of signals that can be used as a signal given by the company to any targeted parties, particularly investors, is a financial report. The report issued by the company reflects the working performance of the company determining its value. Signaling theory can also portray shareholders' reaction to the ups and downs of dividends and retained earnings. If the company increases the dividend payments, investors may interpret it as a signal of the manager's expectations about the increasing company's working performance. Conversely, a decrease in dividend payments will be seen as a degrading company's prospect (Winarto, 2015). When a company makes profit, try to find new funds and avoid selling stocks. 


\subsection{The Firm's Value}

A company aims to increase the stakeholders' level of prosperity which can be reflected through the high stock prices as the impact of the dividend payout ratio (Wibowo \& Aisjah, 2013). The escalation of the stock prices is a perception of a great company's value that can enhance the owner's prosperity (Wijaya \& Sedana, 2015). The firm's value is an important indicator of how the market can judge the firm's value as a whole. The high stock price will also make the firm's value high. Thus, the rise of the stock prices shows that investors give high values to the company (Sasurya and Asandimitra, 2013). The firm's values are measured with Price to Book Value (PBV), a comparison of market stock prices with book stock value. This ratio calculates the market's value given by the financial market to the company's management or organization as a growing company. The higher the ratio scale is, the more expensive the stock prices will be that result in greater firm's value (Anita \& Yulianto, 2016). The book value per share is the distribution between total equity and total circulating shares.

\subsection{Capital Structure}

Capital structure is a combination of debt and equity that results in a company's long-term funding structure (Amelia \& Khaerunnisa, 2016). An optimum capital structure means that a company maximizes the mixture of debt and equity to obtain the highest firm's value. A maximum firm's value becomes the main goal of financial management because it increases the owner's wealth (stockholders' wealth). A company's optimum capital structure will bring more efficiency to the cost of capital. An efficient market will go along with positive market responses, for instance, the increasing stock price and firm's value. After considering some factors that may influence capital structure, a financial manager decides which funding sources must be picked (Maftukhah, 2013).

\subsection{The Influence of Profitability towards Capital Structure}

Profitability is the ability of a company to gain profits in relation to selling its products, total assets or private capital (Velnampy \& Niresh, 2012). A company that has high profitability will be able to fund its expanses with its capital that is taken from the retained profits. According to the pecking order theory, a company that gains huger profits has bigger internal funding sources and needs to pay for the investment through smaller external funding (Hermuningsih, 2012). This theory depicts that profitability negatively influences capital structure. This is in line with the research conducted by Hermuningsih (2012); Herawati (2013); Munawaroh \& Priyadi (2014). Anjarwati, Chabachib \& Demi (2017), and Musabbihan \& Purnawati (2018) who assert that profitability influences capital structure negatively.

\subsection{The Influence of Firm's Size towards Capital Structure}

The firm's size illustrates how big or how small the company which can be seen from the business types or activities done by the company. A big size company tends to have bigger total assets (Anjarwati, Chabachib \& Demi, 2017). The size of the company will affect the capital structure in which the bigger a company is, the higher its selling progression will be. It then makes a company more confident to sell out new stocks and to ask for a higher loan. It is in line with the research conducted by Sulistiono (2010); Hermuningsih (2012); Novari \& Lestari (2016); and Anjarwati, Chabachib \& Demi (2017) that show a firm's size positively affects the capital structure. 


\subsection{The Influence of Dividend on Capital Structure}

Dividend is half of the company's profit that is shared with the stakeholders (Sumani \& Rachmawati, 2012). The dividend subtlety is a company's decision in determining dividends to the stakeholders. The higher dividend partition will affect the level of the company's loan as the internal fund is allocated to be shared with the stakeholders. Therefore, the company will need more grants to afford its operational activities and will increase its loan which can liven up the modal structure. This is corresponding to the research done by Sumani \& Rachmawati (2012); Maftukhah (2013); and Ulfa (2016) that claim the dividend payment ratio positively affects the modal structure.

\subsection{The Influence of Profitability on the Firm's Value}

The profitability or profit is income minus load and loss during the reporting period (Anjarwati, K., Chabachib, M., \& Demi, 2017). The better the growth of the company's profitability is the better the company's prospects in the future. It can upgrade the company's value and promote the investors to lift the stock demands (Munawaroh \& Priyadi, 2014). The number of asset returns has a relation to the firm's value in which the higher level of assets return will affect the company to obtain higher income that can enhance its value. This is corresponding to the research conducted by Chen \& Chen (2011); Winarto (2015); Novari \& Lestari (2016); Novari \& Lestari (2016); Sabirin \& Sujono (2016); and Anjarwati, Chabachib \& Demi (2017) who assert that profitability positively influences the firm's value.

\subsection{The Influence of Firm's Size to the Firm's Value}

The firm's size depicts how big the firm's activities are. Generally, the bigger the size of the firm is, the bigger the business activities are (Fauzi, 2015). The size of the company will affect the firm's value where the bigger the company is, the higher the selling growth is. It then results in creating profits that will affect the firm's value. The result of the research is in line with the signaling theory concept which is becoming a signal that a big size firm is having a bright prospect in the future and bringing a great impact to the firm's value (Anjarwati, K., Chabachib, M., \& Demi, 2017). This is in line with the research conducted by Sunarto \& Budi (2014); Novari \& Lestari (2016) and Anjarwati, K., Chabachib, M., \& Demi (2017). who state that the firm's size positively influences the firm's value.

\subsection{The Influence of Dividend to the Firm's Value}

The dividend payout ratio is about a matter of the use of profit that becomes the rights of the stakeholders. The profit is being shared as dividends or detained to be reinvested. Therefore, the profit that will be shared and when to be detained by paying attention to the firm's goal is to enhance the company's value (Herawati, 2013). Prastuti \& Sudhiarta (2016) exclaim that the firm's value can be reflected through the company's ability to pay the dividend. The higher the dividend payment is, the better the firm's value is. The dividend payment that is done at the moment is better than the capital gain in the future as the obtained dividend from the investors today is more definite. This is corresponding to the research conducted by Winarto (2015); Rehman (2016); Prastuti \& Sudhiarta (2016) and Musabbihan \& Purnawati (2018), who claim that the dividend payout ratio is positively affecting the firm's value. 


\subsection{The Influence of Capital Structure on the Firm's Value}

The capital structure is a proportion of the company's expenditure needs with the long term funding source taken from the external funding (Chen \& Chen, 2011). If the position of the capital structure is under the optimum point, every loan escalation will enhance the firm's value. Reversely, if the capital structure is above the optimum point, every loan escalation will decrease the firm's value (Yuan \& Jia, 2010). This is corresponding to the trade-off theory concept that states the increase of the loan ratio in the capital structure will give an effect on the increasing firm's value. This is in line with the research done by Velnampy \& Niresh (2012); Hermuningsih (2012). Prastuti \& Sudhiarta (2016) and Musabbihan \& Purnawati (2018) who claim that the capital structure affects the firm's value positively.

\subsection{The Influence of Profitability to the Firm's Value: Capital Structure Intervention}

Profitability is an indicator in measuring the financial performance in a company that can be a matrix to judge the company (Sastrawan, 2016). The high profitability of a company gives a signal that it has a good financial performance. The manager then can utilize the company's profit to optimize the capital structure. When the capital structure is optimum, the investors will be more convinced and can boost the stock prices that will give an effect on the enhancement of the firm's value. This is in line with the research done by Hermuningsih (2012); Anjarwati, Chabachib \& Demi (2017); and Musabbihan \& Purnawati (2018)who exclaim that the capital structure can intervene the influence of profitability towards the firm's value.

\subsection{The Influence of Firm's Size to the Firm's Value: Capital Structure Intervention}

The size of a company is an indicator that can show the financial strength of a company (Sulistiono, 2010). A big size company is more convincing from the eye of the investors so that the company can collect a lot more information and funding sources more easily in which can lift the firm's value up. The bigger the company's size is, the easier it acquires the loans from the creditors as the company has a bigger probability to win the competition (Anjarwati, Chabachib \& Demi, 2017). This is corresponding to the research done by Hermuningsih (2012) who elucidate that the capital structure can intervene the influence of the size of a company towards its value.

\subsection{The Influence of Dividend Payout Ratio to the Firm's Value: Capital Structure Intervention}

A dividend is half of the company's profit that is shared with the stakeholders (Ulfa, 2016). In order to obtain a high company's value, a company needs to enhance the dividend that is being shared with the stakeholders. However, the increasing firm's value cannot be separated from the role of the company's capital structure. It is because when the dividend division is high, the amount of loan as the external funding within a company's operations is increasing. This happens due to the internal funding sources that have been allocated to the dividend division (Firnanti, 2011).

According to the description above, some hypotheses can be built in this research:

$\mathrm{H}_{1}$ : The profitability negatively influences the capital structure

$\mathrm{H}_{2}$ : The firm's size positively influences the capital structure

$\mathrm{H}_{3}$ : The dividend payout ratio positively influences the capital structure

$\mathrm{H}_{4}$ : Profitability positively influences the firm's value

$\mathrm{H}_{5}$ : The firm's size positively influences the firm's value 
$\mathrm{H}_{6}$ : The dividend payout ratio positively influences the firm's value

$\mathrm{H}_{7}$ : The capital structure positively influences the firm's value

$\mathrm{H}_{8}$ : The capital structure intervenes the influence of profitability towards the firm's value

$\mathrm{H}_{9}$ : The capital structure intervenes the influence of the firm's size towards the firm's value

$\mathrm{H}_{10}$ :The capital structure intervenes the influence of the dividend payout ratio towards the firm's value.

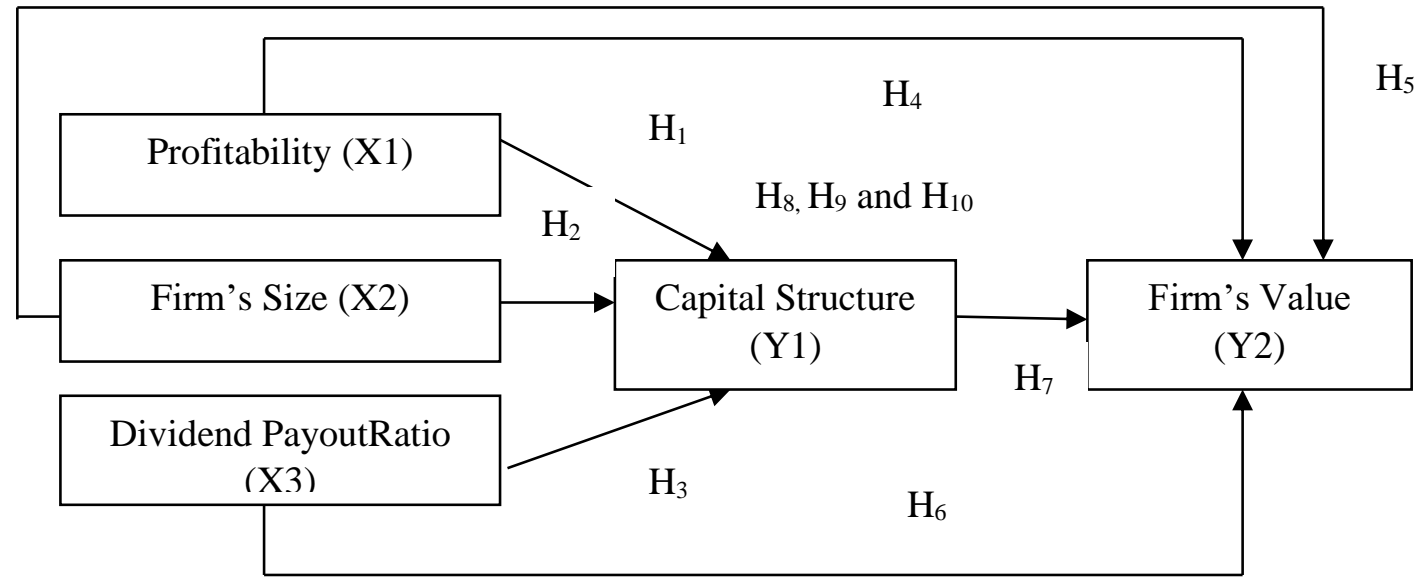

Figure 1. Research Model

\section{RESEARCH METHODOLOGY}

The populations in this research were companies that are listed on the Indonesia Stock Exchange with 539 companies. The samples of this research were 35 manufacturing companies that were included in the population throughout three years of observation with 105 observations in total. The method of the sample taking was purposive sampling, with a certain criteria as follows: manufacturing company listed on the Indonesia Stock Exchange for the last three years starting from 2016 to 2018 and appeared there in every year; a company published an annual report ended on 31 December during the observation period; the company's financial report does not experience any loss and does allocate the dividend throughout 2016 to 2018.

The data employed were secondary data, for instance, the collected database from the Indonesia Stock Exchange in a form of companies' annual reports that were listed on it. There were some research variables used in this research: (1) independent variables, they are profitability (ROA), firm's size (SIZE), and dividend payout ratio (DPR); (2) dependent variable, that is firm's value (PVB); and (3) intervening variable, that is capital structure (DER). The company's profitability was measured by the Return on Asset (ROA) ratio showing the ability of a company by making use of all the assets to make the net profits after tax (Rubiyani \& Yuniati, 2016). The firm's size is a portrayal of how big or small the company is that can be measured using the total assets or net selling of the company (Hidayati, 2010). The dividend payout ratio (DPR) is measured by the dividend payment ratio. DPR ratio is obtained by sharing every sheet of the dividends with the net profit every stock sheet.

The firm's value is defined as a company's normal value illustrating the investors' perceptions towards the corresponding issuers, and as a company's common value reflected through the Price to Book Value (PBV) ratio. The PBV value was obtained by comparing the price of each stock sheet with the book's value and was measured by the ratio scale and was stated in 
the time unit (Sabrin \& Sujono, 2016). The capital structure was measured by the Debt to Equity Ratio (DER), which was ratio illustrating the capital composition used as the funding sources (Anjarwati, Chabachib, \& Demi, 2017). The data analysis technique in this research was path analysis. It aimed to analyze the relationship pattern among variables to know both the direct and indirect influences of the independent variables or exogenous towards the dependent variable or endogenous. The capital structure in this research can be separated into two sub-structural similarities:

Similarity 1: sub-structure 1

$D E R=p_{y l x 3} R O A+p_{y l x 2} S I Z E+p_{y l x 1} D P R+e_{1}$

Similarity 2: sub-structure 2

$P B V=p_{y 2 x 3} R O A+p_{y 2 x 2} S I Z E+p_{y 2 x l} D P R+p_{y 2 y l} D E R+e_{2}$

Note :

$e_{1,2} \quad=$ residue variable,

$p_{y I x] \ldots .} p_{n, n} \quad=$ coefficient path (standardized coefficientregression),

ROA = profitability,

SIZE $\quad$ = firm's size,

$D P R \quad=$ dividend payout ratio,

DER = capital structure,

$P B V \quad=$ firm's value.

\section{RESULT AND DISCUSSION}

Before conducting the hypothesis test, it is suggested to check the descriptive statistics of the research variables, such as ROA, SIZE, DPR, DER, and PBV. The descriptive statistics of the research variables can be seen in Table 1 below:

Table 1. Descriptive Statistical Variables

Investigated Throughout 2016-2018

\begin{tabular}{lllllll}
\hline No. & Information & ROA & SIZE & DPR & DER & PBV \\
\hline 1. & N Valid & 105 & 105 & 105 & 105 & 105 \\
2. & Mean & 0,162708 & 21,520078 & 0,333151 & 0,369745 & 1,644820 \\
3. & Std. Deviation & 0,381089 & 2,540862 & 0,167873 & 0,491787 & 1,916214 \\
4. & Minimum & 0,009592 & 15,495064 & 0,018000 & 0,018174 & 0,016560 \\
5. & Maximum & 3,708478 & 26,815184 & 0,8000000 & 1,728455 & 6,446992 \\
\hline
\end{tabular}

The result of the feasibility test for the first and second regression models in this research can be seen in table 2 . Both of the regression models are feasible to investigate as the two regression models have a significance value of $\leq 0,05$.

Table 2. F Test Result

\begin{tabular}{ccccc}
\hline \multirow{2}{*}{ Regression } & \multicolumn{2}{c}{ ANOVA } & Sig. *Critical & Information \\
\cline { 2 - 4 } & $\begin{array}{c}\mathbf{F} \\
\text { Calculation }\end{array}$ & Sig. & & \\
\hline Model 1 & 12,967 & 0,000 & 0,05 & Feasible model \\
Model 2 & 4,815 & 0,001 & 0,05 & \\
\hline
\end{tabular}


The result of the $\mathrm{R}^{2}$ test for the first and second regression model shows that the regression model 1 of the $\mathrm{R}^{2}$ is 0.278 or $27.8 \%$. Then the $\mathrm{R}^{2}$ for the regression model 2 is 0.561 or $56.1 \%$. The determination coefficient for the regression model 1 depicts that $27.8 \%$ of the DER variable alteration can be explained by the ROA, SIZE, and DPR variables and the rest of $72.2 \%$ can be explained the other factors. Meanwhile, the determination coefficient in the regression model 2 shows that $56.1 \%$ of the PBV variable alteration can be explained by the ROA, SIZE, DPR, and DER variables, and the rest of $43.9 \%$ is explained by the other factors.

The classic assumption test in this research includes normality tests, heteroskedasticity, multicollinearity, and autocorrelation. The result of the normality test using the KolmogorovSmirnov test that model 1 has assumption. Sig.value $(0,470)>$ alpha $(0,05)$. It can be concluded that model 1 has fulfilled the normality assumption. Meanwhile, model 2 has assumption. Sig.value $(0,168)>$ alpha $(0,05)$. It can be concluded that model 2 has also fulfilled the normality assumption. This brings up the whole things of both regression models 1 and 2 have fulfilled the normality test and are feasible to be tested in the next classic assumption test.

Heteroskedasticity test results using the Glejser method for regression models 1 and 2 do not experience any heteroskedasticity symptoms. This happens because the ROA, SIZE, DPR, and DER variables have Sig. value $>0,05$. In conclusion, both regression models 1 and 2 in this research do not experience any heteroskedasticity symptoms. Furthermore, the multicollinearity test using VIF (Variance Inflation Factor) value on regression models 1 and 2 does not experience any multicollinearity symptoms. This happens because of the VIF value on ROA, SIZE, DPR, and DER variables $<10$. The autocorrelation test result by considering the Durbin Watson (DW) value on regression model 1 and 2 do not have any autocorrelation issues. This happens because the DW value is located between $\mathrm{dU}$ and $(4-\mathrm{dU})$.

This research using SPSS to obtain regression analysis results on a path diagram and a standardized coefficient. Figure 2 below depicts the coefficient value of a path for each independent variable (exogenous variable) towards the dependent variable (endogenous variable). The coefficient of other variables' influence (residue variable) towards the dependent variable using the following formula $e=\sqrt{1-R^{2}}$ in which $\mathrm{R} 2$ is the determined coefficient. Regression model 1: the value of other variables' influence toward DER variable obtained from:

$e_{1}=\sqrt{1-0,278}=\sqrt{0,722}=0,850$

Regression model 2: the value of other variables' influence toward PBV variable obtained from:

$e_{2}=\sqrt{1-0,561}=\sqrt{0,439}=0,663$

Therefore, the model structure for the path diagram above can be formulated as follows:

Model 1: DER $=-0,130 \mathrm{ROA}+0,527 \mathrm{SIZE}+0,145 \mathrm{DPR}+0,850 \mathrm{e}_{1}$

Model 2: PBV = 0,146 ROA + 0,189 SIZE + 0,299 DPR + 0,288 DER + 0,663 $\mathrm{e}_{2}$ 


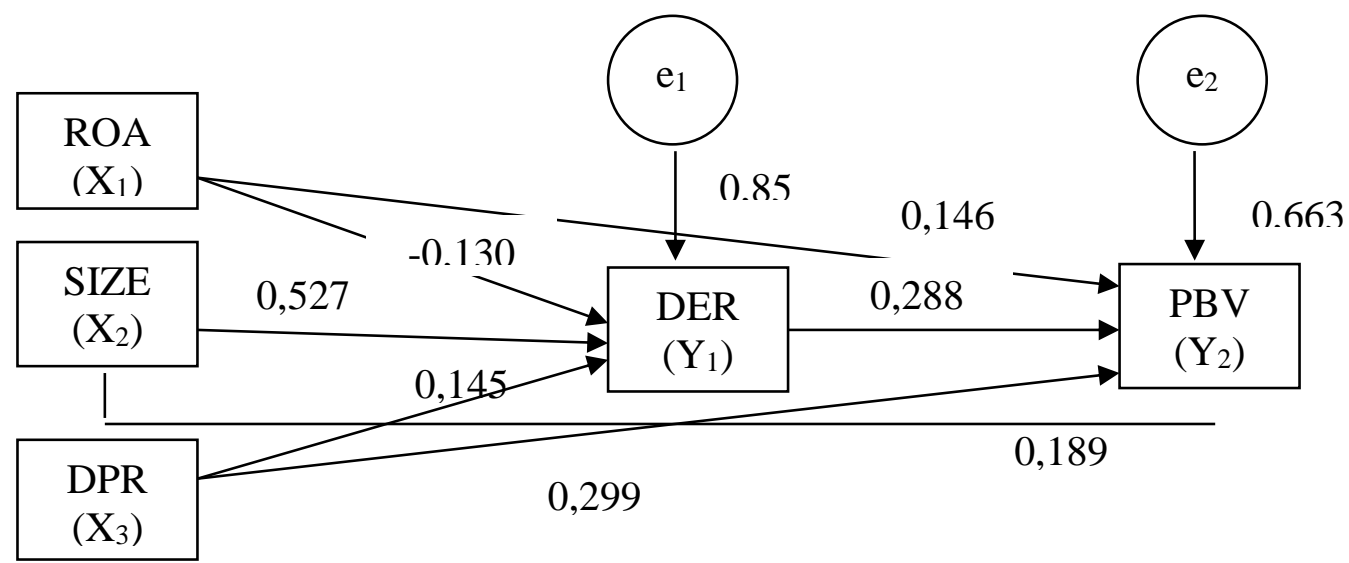

Figure 2. Path Diagram Analysis Result

In order to do the research's hypotheses test, a test on the significance value of the path coefficient on each resulted variable can be done.

Table 3. The Hypothesis Test Result of the Path Coefficient

\begin{tabular}{ccccc}
\hline Variable Relation & $\begin{array}{c}\text { Standardized } \\
\text { Coefficient }\end{array}$ & Significance Value & *Sig. Tolerance & Information \\
\hline ROA $\rightarrow$ DER & $-0,130$ & 0,030 & 0,05 & Significant \\
SIZE $\rightarrow$ DER & 0,527 & 0,080 & 0,05 & Not Significant \\
DPR $\rightarrow$ DER & 0,145 & 0,094 & 0,05 & Not Significant \\
ROA $\rightarrow$ PBV & 0,146 & 0,020 & 0,05 & Significant \\
SIZE $\rightarrow$ PBV & 0,189 & 0,037 & 0,05 & Significant \\
DPR $\rightarrow$ PBV & 0,299 & 0,002 & 0,05 & Significant \\
DER $\rightarrow$ PBV & 0,288 & 0,009 & 0,05 & Significant \\
\hline
\end{tabular}

Table 9 showing the result of the research's hypotheses test based on the path coefficient test can be explained as follows: Hypothesis 1 claiming that profitability negatively influences the capital structure. The negative standardized coefficient value is -0.130 and the significance value is 0.030 . Thus, the significance value $(0.030)<$ sig. tolerance $(0.05)$ and the $\mathrm{H}_{\mathrm{a}}$ is rejected, while $\mathrm{H}_{0}$ is accepted where the profitability negatively influences the capital structure proving it significant.

Hypothesis 2 claiming that firm's size positively influences the capital structure. The positive standardized coefficient value is 0.527 and the significance value is 0.080 . Thus, the significance value $(0.080)>$ sig. tolerance $(0.05)$ and the $\mathrm{H}_{\mathrm{a}}$ is rejected, while $\mathrm{H}_{0}$ is accepted where the firm's size positively influences the capital structure proving it not significant. Hypothesis 3 claiming that dividend payout ratio positively influences the capital structure. The positive standardized coefficient value is 0.145 and the significance value is 0.094 . Thus, the significance value $(0.080)>$ sig. tolerance $(0.05)$ and the $\mathrm{H}_{0}$ is rejected, while $\mathrm{H}_{\mathrm{a}} \mathrm{is}$ accepted where the dividend payout ratio positively influences the capital structure proving it not significant.

Hypothesis 4 claiming that profitability positively influences the firm's value. The positive standardized coefficient value is 0.146 and the significance value is 0.020 . Thus, the significance value $(0.020)>$ sig. tolerance $(0.05)$ and the $\mathrm{H}_{0}$ is rejected, while $\mathrm{H}_{\mathrm{a}}$ is accepted where the profitability positively influences the firm's value proving it significant. Hypothesis 5 claiming 
that firm's size positively influences the firm's value. The positive standardized coefficient value is 0.189 and the significance value is 0.037 . Thus, the significance value $(0.037)>$ sig. tolerance (0.05) and the $\mathrm{H}_{\mathrm{a}}$ is rejected, while $\mathrm{H}_{0}$ is accepted where the firm's size positively influences the firm's value proving it significant.

Hypothesis 6 claiming that dividend payout ratio positively influences the firm's value. The positive standardized coefficient value is 0.299 and the significance value is 0.002 . Thus, the significance value $(0.002)>$ sig. tolerance $(0.05)$ and the $\mathrm{H}_{0}$ is rejected, while $\mathrm{a}_{0}$ is accepted where the dividend payout ratio positively influences the firm's value proving significant. Hypothesis 7 claims that capital structure positively influences the firm's value. The positive standardized coefficient value is 0.288 and the significance value is 0.009 . Thus, the significance value (0.009) > sig. tolerance (0.05) and the $\mathrm{H}_{0}$ is rejected, while $\mathrm{H}_{\mathrm{a}}$ is accepted where the capital structure positively influences the firm's value proving it significant.

This research was using path analysis to know whether the capital structure variable is intervening from the ROA, SIZE, and DPR variables' influence towards the PBV variable.

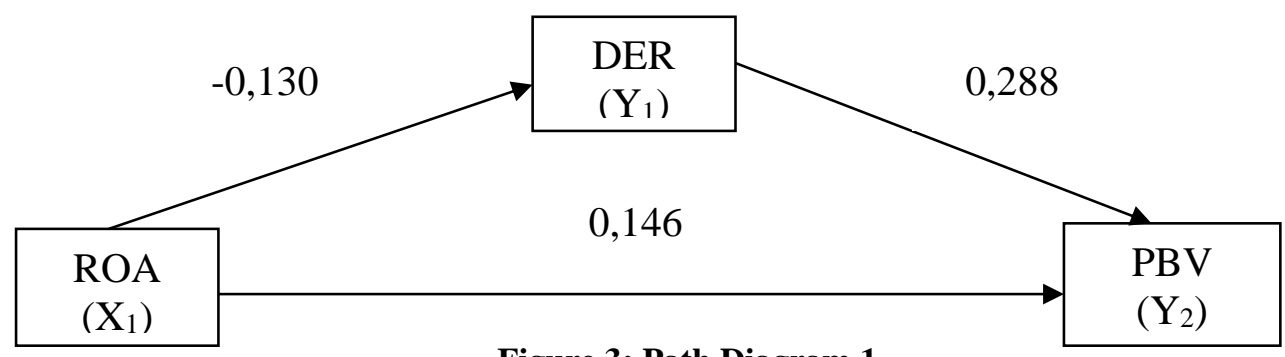

Figure 3: Path Diagram 1

Hypothesis 8 claiming that the capital structure intervenes the profitability influence towards the firm's value. According to the path coefficient hypothesis test result in table 3, the ROA variable significantly influences the DER variable. Meanwhile, the DER variable significantly influences the PBV variable or all of the lines connecting ROA, DER, and PBV. Therefore, the capital structure successfully intervenes the profitability influence towards the firm's value. It proves that profitability gives a significant effect on the capital structure. Figure 3 above can be explained as follows: direct relation $=0,146$, indirect relation $=(-0,130 \times 0,288)=$ $-0,037$. Therefore, the total influence of the profitability towards firm value through the capital structure $=0,146+(-0,130 \times 0,288)=0,109$.

Hypothesis 9 claiming that capital structure policy intervenes the influence of the firm's size towards the firm's value. According to the path coefficient hypothesis test result in Table 3, the SIZE variable does not significantly influence the DER variable. Meanwhile, the DER variable significantly influences the PBV variable or not all of the lines connecting SIZE, DER, and PBV. Therefore, the capital structure does not successfully intervene the firm's size influence towards the firm's value. It proves that the firm's size does not give any significant effect on the capital structure. Figure 4 below can be explained as follows: direct relation $=0,189$, indirect relation $=(0,527 \times 0,288)=0,152$. Therefore, the total influence of the firm's size towards firm's value through the capital structure $=0,189+(0,527 \times 0,288)=0341$. 


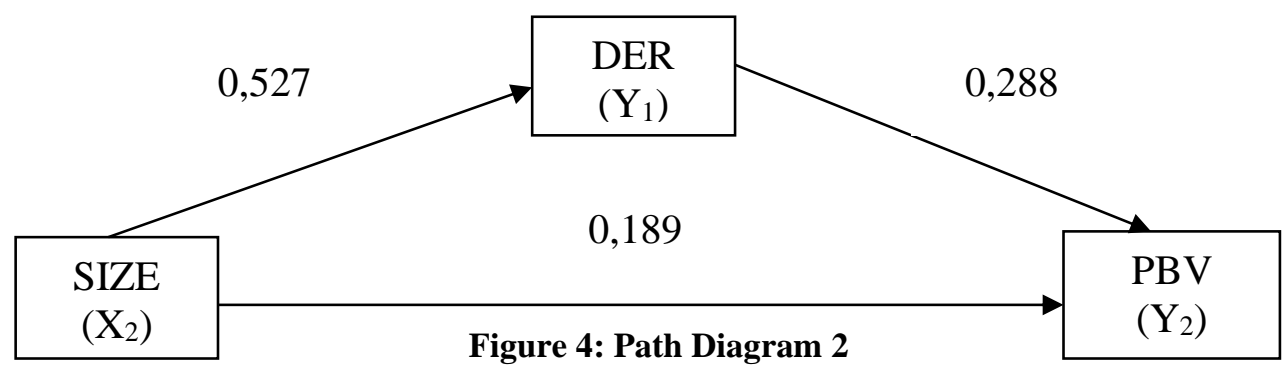

Hypothesis 10 claims that capital structure policy intervenes the influence of the dividend payout ratio towards the firm's value. According to the path coefficient hypothesis test result in table 9, the DPR variable does not significantly influence the DER variable. Meanwhile, the DER variable significantly influences the PBV variable or not all of the lines connecting DPR, DER, and NP. Therefore, the capital structure does not successfully intervene the dividend payout ratio's influence towards the firm's value. It proves that the dividend payout ratio does not give any significant effect on the capital structure. Figure 5 below can be explained as follows: direct relation $=0,299$, indirect relation $=(0,145 \times 0,288)=0,042$. Therefore, the total influence of the dividend payout ratio towards firm's value through the capital structure $=0,299+(0,145 \times 0,288)$ $=0,341$.

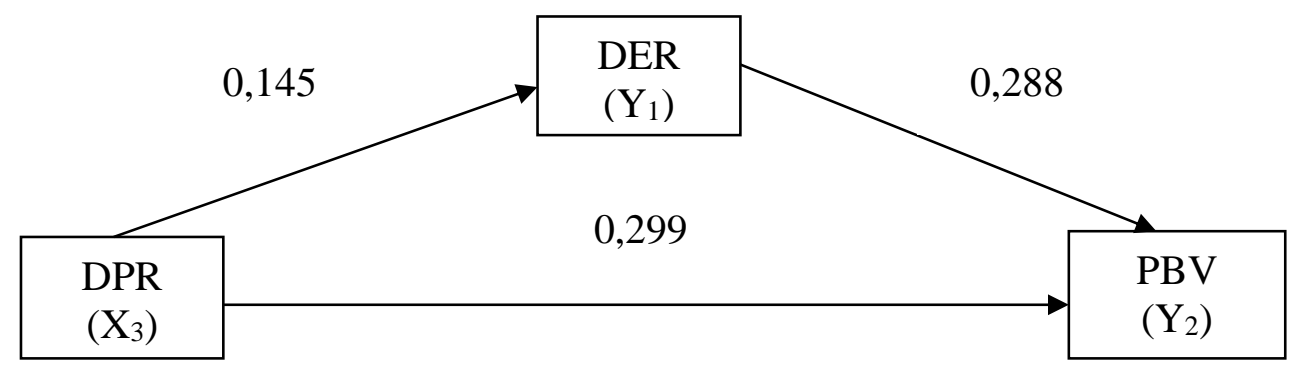

Figure 5: Path Diagram 3

The first hypothesis in this research shows that profitability negatively influences the capital structure in an asignificant way. This result supports the research result conducted by Hermuningsih (2012); Herawati (2013); Munawaroh \& Priyadi (2014). Anjarwati, Chabachib \& Demi (2017); and Musabbihan \& Purnawati (2018). However, the result of this study does not support the research result from Wijaya \& Sedana (2015); and Musabbihan \& Purnawati (2018) that assert the profitability positively influence the capital structure in a significant way. The result of this research shows if the profitability enhances, the capital structure will decrease instead. A company that has high profitability might have a big amount of retained profits as its internal funding sources. Therefore, the company will make use of the internal funding sources first to expand the capital and to pay the business activities. The external funding sources (debt) will be utilized afterward to cover up the deficiency.

The second hypothesis in this research shows that the firm's size insignificant influences the capital structure in a significant way. This result supports a research result conducted by Anjarwati, Chabachib \& Demi (2017). However, the result of this research does not match with a research result done by Firnanti (2010) and Novitaningtyas \& Mudjiyanto (2014) claiming that the 
firm's size insignificant affects the capital structure. The result depicts that the size of the firm does not give any effect on the decision of having debt in the capital structure. This happens as a big company might not show its incapability to pay the business activities using internal funding sources. Meanwhile, the smaller company might not have a big debt.

The third hypothesis of this research shows that the dividend payout ratio insignificant influences the capital structure in a significant way. This result supports a research result conducted by Sangeetha \& Sivathaasan (2013); Lestari \& Hermanto (2015); and Musabbihan \& Purnawati (2018). However, the result of this research does not match with a research result done by Fauzi (2015) and Laksana \& Widyawati (2016) claiming that the dividend payout ratio insignificant affects the capital structure. This research result also shows that a company will use the external funding sources as tax retrenchment from the debt. The increase of the capital structure occurs because a company judges that having debt is more beneficial compared to the immolation of the use of it. Thus, a company will utilize the external funding sources to a certain level, even though the internal funding sources have been reduced with the dividend division and it is still enough to cover up the company's business activities (Rakhimsyah \& Gunawan, 2011).

The fourth hypothesis of this research shows that profitability positively influences the firm's value in in a significant way. This result supports a research result conducted by Chen \& Chen (2011); Winarto (2015); Novari \& Lestari (2016); Sabrin \& Sujono (2016) and Anjarwati, Chabachib \& Demi (2017). However, the result of this research does not match with a research result done by Herawati (2013) and Munawaroh \& Priyadi (2014). claiming that profitability negatively affects the firm's value. This research result also shows the increase in the profitability will enhance the firm's value. The higher a company creates profitability, the greater the company's performance in the future will be. It gives an effect on the investors who will positively respond to and judge the company. Thus, this thing will improve the firm's value seen from the rise of its stocks prices.

The fifth hypothesis of this research shows that the firm's size positively influences the firm's value in in a significant way. This result supports a research result conducted by Sulistiono (2010); Novari \& Lestari (2016) and Anjarwati, Chabachib \& Demi (2017). However, the result of this research does not match with a research result done by Prastuti \& Sudhiarta (2016) and Wiyono (2017) claiming that the firm's size negatively affects the firm's value in a significant way. This research result also shows that the bigger the size of a company is, the more stable the company's condition will be. That condition causes the rise of the stocks' price of the company and positive responses from the investors in the form of dividend division. Therefore, the increase in the company's stock demand can elevate the price of its stocks hoisting the firm's value.

The sixth hypothesis of this research shows that the dividend payout ratio positively influences the firm's value in in a significant way. This result supports a research result conducted by Winarto (2015); Rehman (2016). Prastuti \& Sudhiarta (2016) and Musabbihan \& Purnawati (2018). However, the result of this research does not match with a research result done Hidayati (2010); Rakhimsyah \& Gunawan (2011), Wibowo \& Aisjah (2013), and Anita \& Yulianto (2016) claiming that the dividend payout ratio negatively affects the firm's value in in a significant way. This research result also shows that the rise of the dividend distributed to the stakeholders is the signal of the rising of the company's performance hoisting its value. This is in line with the bird in the hand theory defining that investors are more likely to choose companies that share dividends. 
It is because there is a certainty on investment return from the investors' investment and it can reduce the company's bankruptcy risk. The risk of the stock division is smaller than the capital gain. Therefore, the higher the dividend is paid to, the smaller the capital gain that will affect the rise of the company's value (Rehman, 2016).

The seventh hypothesis of this research shows that the capital structure positively influences the firm's value in in a significant way. This result supports a research result conducted by Velnampy \& Niresh (2012); Hermuningsih (2012); Prastuti \& Sudhiarta (2016) and Musabbihan \& Purnawati (2018). However, the result of this research does not match with a research result done by Hidayati (2010) claiming that the capital structure negatively affects the firm's value in a significant way. This research result also shows that the use of external funding sources policy will give a signal to the investors through the funding policy and will result in the rise of the firm's value. This is in line with the trade-off theory claiming that if the capital structure is under the optimum limit, every enhancement of external funding sources will improve the company's value. However, if the capital structure is above the optimum limit, every enhancement of external funding sources will lower the company's value (Yuan \& Jia, 2010).

The eighth hypothesis of this research shows that the capital structure intervenes the influence of the profitability towards the firm's value. This result supports a research result conducted by Anjarwati, Chabachib \& Demi (2017); and Musabbihan \& Purnawati (2018). This research result also shows that the enhancement of the capital structure value will give an effect on the profitability value towards the firm's value. This occurs because the result of the profitability variable partial test towards each capital structure and firm's value shows a significant influence. Profitability directly affects the firm's value positively and significantly that is showing the rise of the company's value and the great responses from the investors. Therefore, it gives a signal that the company has done decent performances resulting in the greater firm's value. However, the rise of a company's value also happens because of the existence of a capital structure within. If a company makes a capital structure decision on the right time or the right business activity, the company's value will be also increasing.

The ninth hypothesis of this research shows that the capital structure does not intervene the influence of the firm's size towards the firm's value. This result supports a research result conducted by Hermuningsih (2012) and Anjarwati, Chabachib \& Demi (2017). This research result also shows that the enhancement of the capital structure will not necessarily give an effect on the firm's size towards the firm's value. This occurs because the result of the firm's value variable partial test towards each capital structure and firm's value shows an insignificant influence. The firm's size directly affects the firm's value positively and significantly showing the investors that a bigger-sized company is likely to be a decent one in terms of performance. Therefore, it also gives an impact on the increase of stocks' price and the firm's value. However, a big-sized company is not necessarily able to afford all of its operational activities with the intern funding sources.

The tenth hypothesis of this research shows that the capital structure does not intervene the influence of the dividend payout ratio towards the firm's value. This result supports a research result conducted by Musabbihan \& Purnawati (2018). This research result also shows that the higher the dividend payout ratio will increase the capital structure of a company to exceed the optimum limit that will lower its value. The capital structure above the optimum limit gives a sign 
that the interest expense owned by the company is beyond its potency. Furthermore, the benefits for the company are fewer than the sacrifices in having the debt. It thus can make the company bankrupt and lower its value. Therefore, the capital structure variable in this research cannot intervene the influence of the dividend payout ratio towards the firm's value.

\section{CONCLUSION AND RECOMMENDATION}

According to the results of the research, it can be concluded that: (1) the profitability negatively influences the capital structure in a significant way; (2) the firm's size and dividend payout ratio insignificant influences the capital structure in a significant way; (3) the profitability, firm's size, dividend payout ratio, and structure capital positively influence the firm's value in a significant way; (4) the capital structure intervenes the influence of the profitability towards the firm's value; and (5) the capital structure does not intervene the influence of the firm's size and dividend payout ratio towards the firm's value.

After analyzing the data of this research, there are some suggestions proposed by the writer: (1) for companies, companies are suggested to improve their profitability, commit to paying a higher dividend and select big-sized companies by balancing the capital structures to set the external funding sources above the optimum limit so that it can maximize the company's value; (2) for investors, investors are suggested to select companies that have high profitability values and offer high dividend payment, so that their stock's values will improve and investors can collect more capital gain. Besides, investors are also suggested to choose big-sized companies that are showing promising prospects now and in the future; (3) for the future researchers, the future researchers may add mediating variables and other factors influencing the company's values other than profitability, firm's size, and dividend payout ratio.

Regarding the research limitation, this study has insufficient sample size because the vast majority of issuers did not issue dividends on a yearly basis. Future researchers are suggested to extend the observation process to acquire more comprehensive results. Furthermore, this research discusses the trade-off theory but does not specifically discuss the limitation of agency problems.

\section{REFERENCES}

Amelia, Y. R., \& Khaerunnisa, E. (2016). Pengaruh Pertumbuhan Perusahaan dan Profitabilitas terhadap Nilai Perusahaan dengan Struktur Modal sebagai Variabel Interverning. Jurnal Riset Akuntansi Terpadu, 9(1), 109-119. https://doi.org/10.35448/jrat.v9i1.4290

Anita, A., \& Yulianto, A. (2016). Pengaruh Kepemilikan Manajerial dan Kebijakan Deviden terhadap Nilai Perusahaan. Journal of Reproduction and Infertility, 5(1), 17-23. https://doi.org/10.15294/MAJ.V5I1.8116

Anjarwati, K., Chabachib, M., \& Demi, I. (2017). Pengaruh Profitabilitas, Size, dan Likuiditas terhadap Nilai Perusahaan Manufaktur di Indonesia dengan Struktur Modal sebagai Variabel Intervening. Diponegoro Journal of Finance, 1(3), 1-20. http://eprints.undip.ac.id/56110/

Ayu, D. P., \& Suarjaya, A. A. G. (2017). Pengaruh Profitabilitas terhadap Nilai Perusahaan dengan Corporate Social Responsibility sebagai Variabel Mediasi pada Perusahaan Pertambangan. E-Jurnal Manajemen Unud, 6(2), 1112-1138. https://doi.org/10.24843/EJA.2018.v22.i02.p29 
Chen, S. Y., \& Chen, L. J. (2011). Capital Structure Determinants: An Empirical Study in Taiwan. African Journal of Business Management, 5(27), 10974-10983. https://doi.org/10.5897/ajbm10.1334

Fauzi, M. N. (2015). Pengaruh Kebijakan Dividen dan Pertumbuhan Perusahaan terhadap Struktur Modal dan Profitabilitas (Studi Pada Sektor Mining yang Terdaftar di Bursa Efek Indonesia Periode 2011-2013). Jurnal Administrasi Bisnis (JAB), 24(1), 1-10. http://administrasibisnis.studentjournal.ub.ac.id/index.php/jab/article/view/956

Firnanti, F. (2011). Faktor-Faktor yang Mempengaruhi Struktur Modal Perusahaan Manufaktur di Bursa Efek Indonesia. Jurnal Bisnis Dan Akuntansi, 13(2), 119-128. https://doi.org/10.32546/lq.v5i1.61

Herawati, T. (2013). Pengaruh Kebijakan Deviden, Kebijakan Hutang dan Profitabilitas terhadap Nilai Perusahaan. Jurnal Manajemen, 2(2), 1-18. https://jurnaltsm.id/index.php/JBA/article/view/153/123

Hermuningsih, S. (2012). Pengaruh Profitabilitas, Size terhadap Nilai Perusahaan dengan Sruktur Modal sebagai Variabel Intervening. Jurnal Siasat Bisnis, 16(2), 232-242. https://doi.org/10.20885/jsb.vol16.iss2.art8

Hidayati, E. E. (2010). Analisis Pengaruh DER, DPR, ROE dan Size terhadap PBV Perusahaan Manufaktur yang Listing di BEI Periode 2005-2007. Jurnal Bisnis Strategi, 19(2), 166-174. https://doi.org/10.14710/jbs.19.2.166-174

Jensen, M.C., \& Meckling, W. (2011). Simultaneous Determination of Insider Ownership, Debt, and Dividend Policies. Journal of Financial and Quantitative Analysis, 27(2), 247-263. https://doi.org/10.2307/2331370

Jusriani, I. F. (2012). Analisis Pengaruh Profitabilitas, Kebijakan Deviden, Kebijakan Utang dan Kepemilikan Manajerial terhadap Nilai Perusahaan (Studi Empiris pada Perusahaan Manufaktur yang Terdaftar di Bursa Efek Indonesia Periode 2009-2011). Diponegoro University. http://eprints.undip.ac.id/39008/1/JUSRIANI.pdf

Laksana, I. F., \& Widyawati, D. (2016). Pengaruh Kepemilikan Saham, Kebijakan Dividen, Tangibility, Size, dan Profitabilitas terhadap Struktur Modal. Jurnal Ilmu dan Riset Akuntansi, 5(4), 1-18. http://jurnalmahasiswa.stiesia.ac.id/index.php/jira/article/view/1692/1702

Maftukhah, I. (2013). Kepemilikan Manajerial, Kepemilikan Institusional dan Kinerja Keuangan sebagai Penentu Struktur Modal Perusahaan. Jurnal Dinamika Manajemen, 4(1), 69-81. https://doi.org/10.15294/jdm.v4i1.2425

Munawaroh, A., \& Priyadi, M. P. (2014). Pengaruh Profitabilitas terhadap Nilai Perusahaan dengan Corporate Social Responsibilty sebagai Variabel Moderating. Jurnal Ilmu Dan Riset Akuntansi, 3(4), 1-17. https://doi.org/10.15294/aaj.v3i1.3911

Musabbihan, N. A., \& Purnawati, N. K. (2018). Pengaruh Profitabilitas dan Kebijakan Dividen terhadap Nilai Perusahaan dengan Struktur Modal sebagai Pemediasi. E-Jurnal Manajemen Unud, 7(4), 1979-2009. https://doi.org/10.33059/jmk.v8i2.1414

Muvidha \& Suryono, B. (2017). Pengaruh Struktur Kepemilikan, Keputusan Pendanaan, Profitabilitas, dan Ukuran Perusahaan terhadap Nilai Perusahaan. Jurnal Ilmu dan Riset Akuntansi, 6(5), 1813-1835. https://adoc.pub/pengaruh-profitabilitas-terhadap-nilaiperusahaan-dengan-cor.html 
Nofrita, R. (2013). Pengaruh Profitabilitas terhadap Nilai Perusahaan dengan Kebijakan Deviden sebagai Variabel Intervening (Studi Empiris pada Perusahaan Manufaktur yang Terdaftar di BEI). Jurnal Akuntansi, 1(1), 1-23. ejournal.unp.ac.id > index.php > akt > article > download\%0A

Novari, P., \& Lestari, P. (2016). Pengaruh Ukuran Perusahaan, Leverage, dan Profitabilitas terhadap Nilai Perusahaan pada Sektor Properti dan Real Estate. E-Jurnal Manajemen Unud, 5(9), 5671-5694. https://ojs.unud.ac.id/index.php/Manajemen/article/view/22690/15445

Prastuti, N. K. R., \& Sudhiarta, I. G. M. (2016). Pengaruh Struktur Modal, Kebijakan Dividen, dan Ukuran Perusahaan terhadap Nilai Perusahaan pada Perusahaan Manufaktur. E-Jurnal Manajemen Unud, 5(3), 1572-1598. https://ojs.unud.ac.id/index.php/Manajemen/article/view/16540/13151

Rakhimsyah, L. A., \& Gunawan, B. (2011). Pengaruh Keputusan Investasi, Keputusan Pendanaan, Kebijakan Deviden dan Tingkat Suku Bunga terhadap Nilai Perusahaan. Jurnal Investasi, 7(1), 31-45. https://doi.org/10.15294/maj.v2i2.2517

Rehman, O. U. (2016). Impact of Capital Structure and Dividend Policy on Firm Value. Journal of Poverty, Investment and Development, 21(2006), 40-57. https://iiste.org/Journals/index.php/JPID/article/view/28887

Rubiyani, D., \& Yuniati, T. (2016). Pengaruh Profitabilitas terhadap Firm Value dengan Capital Structure sebagai Variabel Intervening. Jurnal Ilmu Dan Riset Manajemen, 5(4), 1-16. https://doi.org/10.30587/jre.v3i2.1584

Sabrin, B. S., \& Sujono, D. T. (2016). The Effect of Profitability on Firm Value in Manufacturing Company at Indonesia Stock Exchange. The International Journal of Engineering and Science, 5(10), 81-89. https://doi.org/10.25139/dev.v2i2.1071

Sastrawan, I. M. D. (2016). Pengaruh Langsung dan Tidak Langsung Good Corporate Governance terhadap Pengungkapan Tanggung Jawab Sosial Perusahaan. E-Jurnal Akuntansi Universitas Udayana, 14(1), 371-398. https://ojs.unud.ac.id/index.php/Akuntansi/article/view/14504

Sasurya, A. \& Asandimitra, N. (2013). Pengaruh Kepemilikan Manajerial, Keputusan Investasi, Keputusan Pendanaan, dan Kebijakan Deviden terhadap Nilai Perusahaan. BISMA Jurnal Bisnis Dan Manajemen, 6(1), 1-10. https://doi.org/10.26740/bisma.v6n1.p1-10

Sulistiono. (2010). Pengaruh Kepemilikan Manajerial, Struktur Modal dan Ukuran Perusahaan terhadap Nilai Perusahaan pada Perusahaan Manufaktur di BEI Tahun 2006-2008 Universitas Negeri Semarang. http://lib.unnes.ac.id/2612/1/7192.pdf

Sumani \& Rachmawati, L. (2012). Analisis Struktur Modal dan Beberapa Faktor yang Mempengaruhinya pada Perusahaan Manufaktur di Bursa Efek Indonesia. Jurnal Emas, 6(1), 30-41. http://repository.unej.ac.id/handle/123456789/80107

Ulfa, A. (2016). Faktor-Faktor yang Mempengaruhi Kebijakan Deviden dan Dampak Kebijakan Deviden terhadap Struktur Modal Bank BUMN Periode 2005-2014. Perbanas Institute Journals, 2(1), 1-16. https://repository.unej.ac.id/bitstream/handle/123456789/80107/Compile EMAS Vol. 6\%2C No. 1\%2C November 2012.compressed.pdf?sequence=1\&isAllowed=y

Velnampy, T., \& Niresh, J. A. (2012). The Relationship between Capital Structure \& Profitability. Journal of Management and Business Research, 12(13), 66-74. https://journalofbusiness.org/index.php/GJMBR/article/view/766/695

Wibowo, R., \& Aisjah, S. (2013). Pengaruh Profitabilitas, Kepemilikan Manajerial, Kebijakan Dividen, dan Leverage terhadap Nilai Perusahaan. Jurnal Ilmiah Mahasiswa FEB Universitas Brawijaya, 2(1), 1-14. https://jimfeb.ub.ac.id/index.php/jimfeb/article/view/856 
Wijaya, B. I., \& Sedana, I. B. P. (2015). Pengaruh Profitabilitas terhadap Nilai Perusahaan (Kebijakan Dividen dan Kesempatan Investasi sebagai Variabel Mediasi. E-Jurnal Manajemen Unud, 4(12), 4477-4500. https://media.neliti.com/media/publications/253308pengaruh-profitabilitas-terhadap-nilai-p-72a6f72a.pdf

Winarto, J. (2015). The Determinants of Manufacture Firm Value in Indonesia Stock Exchange. International Journal of Information, Business and Management, 7(4), 323-349. http://ijibm.site666.com/IJIBM_Vol7No4_Nov2015.pdf\#page=206

Yuan, W., \& Jia, J. (2010). Institutional Ownership, Managerial Ownership and Dividend Policy In Bank Holding Companies. International Review of Accounting, Banking and Finance, 2(1), 9-22. http://www.irabf.org/upload/journal/prog/2010v2n1.pdf 